\title{
POSTNATAL GROWTH OF THE RABBIT MANDIBLE
}

\author{
S. BANG and D. H. ENLOW \\ Department of Anatomy and Center for Human Growth and Development, \\ The University of Michigan. Ann Arbor, Michigan, U.S.A.
}

\begin{abstract}
Summary-Postnatal growth patterns in the rabbit mandible were studied as a sequel to previous reports dealing with mandibular growth and remodeling in the human and Rhesus monkey. Procedures and methods used in the present work follow those in past studies. The detailed distribution of depository and resorptive surfaces in all areas throughout the mandible was determined. Using this information, overall growth patterns in the entire bone were described and interpreted. Remodeling relationships between the different areas of the mandible were evaluated, and similarities and differences between modes of postnatal growth in the rabbit and human mandibles are discussed. Due to the general similarity of mandibular form in both species, the overall sequence of growth is parallel, including processes of condylar growth, progressive reduction of the condylar neck, and the posterior drift of the ramus. The lingual surface of the ramus in each species is predominantly depository, in contrast to the resorptive nature of the contralateral buccal side in both the human and rabbit. Growth of the mandibular body is also comparable in the two forms. Several major remodeling differences are present, however, and these are associated with certain gross anatomical dissimilarities, including differences in the coronoid process, lingual tuberosity and the mental region. The developmental basis for these differences is explained and discussed.
\end{abstract}

\section{INTRODUCTION}

THE PURPOSE of this study is to provide an account of the remodeling changes and the distribution of resorptive and depository surfaces in the growing mandible of the young rabbit. This species is commonly used in studies of facial growth and in experimental work dealing with tooth-bearing bone. The present study was undertaken to provide information on normal growth patterns in the rabbit as a basis for experimental studies. Comparisons are made with known growth patterns in the human mandible.

\section{MATERIALS AND METHODS}

Twelve New Zealand white rabbits in an age range from 2 to 6 months were used. Intravenous aqueous lead acetate was administered according to standard procedures (SCHEIMAN-TAGGER and BRODIE, 1964) in order to better visualize depository periosteal and endosteal surfaces of the growing bone. ZAK (1963) showed that dosages within the range used do not affect size and weight curves in rabbits. Possible effects of this compound on amounts of bone deposited at the microscopic level are not now known. Comparisons with untreated controls, however, have not shown any influence on the nature of growth patterns involving the actual distribution of resorptive and depository surfaces. Mandibular specimens were removed from sacrificed 
animals $48-72 \mathrm{hr}$ following lead acetate injections, fixed in $10 \%$ neutral formalin and then decalcified. The left half of each mandible was embedded in celloidinparaffin and serially sectioned at $15 \mu$.

The serial sections were analyzed for the detailed regional distribution of resorptive and depository periosteal and endosteal surfaces. Using this information, the mandible as a whole was mapped according to patterns of such surface activity (Figs. 1 and 2). Regional directions of growth throughout all parts of the mandible were then
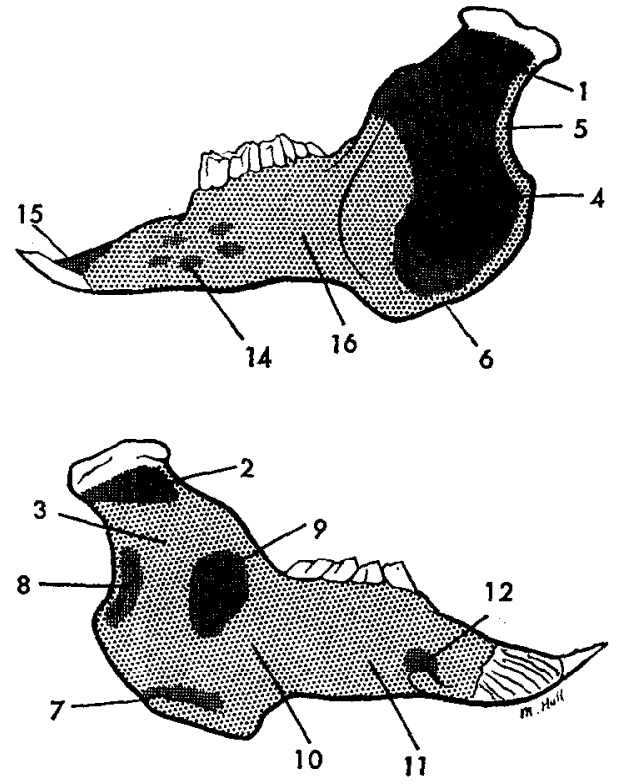

Figs. 1 and 2. Rabbit mandible. Figure 1 is a buccal (lateral) view, and Fig. 2 is a lingual (medial) view. Areas of periosteal deposition are represented by the light stipple pattern, and areas of periosteal resorption are indicated by the darker crosshatch pattern. See text for descriptions.

determined from this information and related with one another. Principles of growth and remodeling applied in previous studies of mandibular growth in the Rhesus monkey (ENLOW, 1963) and the human (ENLOW and HARRIS, 1964) were similarly employed in the present study. These concepts include the principle of "area relocation" and the concept stating that those particular bone surfaces facing actual directions of growth are depository in nature. In contrast, those surfaces facing away from the growth direction are typically resorptive. These and other related principles are discussed in further detail in the reports cited above.

\section{RESULTS}

The bulbous mandibular condyle is responsible for growth of the upper ramus in a cephalic and posterior direction by a process of endochondral bone formation within the condyle itself. Because the adjacent neck of the condyle sequentially occupies a 
position previously held by the condyle during a former growth stage, a direct and continuous remodeling conversion from the growing and moving condyle into the neck takes place. In this process of relocation, the buccal and lingual cortices grow in an actual endosteal direction, with corresponding periosteal resorption, thereby reducing the broad dimensions of the former condyle to that of the more narrow neck. In the accompanying figures it is seen that the outer bone surfaces in both Areas 1 and 2 are resorptive in nature. The posterior margin of the entire ramus (Area 5), however, is depository. This provides a growth movement of the ramus in a posterior course in conjunction with simultaneous resorption along the anterior border of the ramus. These growth activities proceed simultaneously with the remodeling changes occurring in the condylar neck, as described above.

Note that the lingual side of the ramus (Area 3) is largely depository in character in contrast to the buccal surface (Area 4 ) which is primarily resorptive. This combination is associated with the generalized posterior and upward movement of the entire growing ramus. Since the lingual side of the ramus faces the actual upward and posterior direction of growth, its surface thereby receives continued deposits of new bone. The contralateral buccal side, however, faces away from these growth directions and is resorptive in character. This combined pattern of resorption and deposition on opposite sides serves to move the whole ramus in a backward and at the same time a cephalic course in conjunction with corresponding growth movements of the mandibular condyle.

Small localized regions of resorption (with endosteal bone deposition) are present in Areas 8 and 9 on the lingual side of the ramus. The growth reversal in Area 8 is concerned with the marked lateral flare of this region, and its endosteal mode of cortical growth serves to move the area in a lateral direction behind the backwardmoving posterior margin (Area 5). Surface resorption associated with endosteal bone formation in Area 9 produces the characteristic and marked depression located caudally to the mandibular foramen. Continued surface resorption proceeding in a posterior direction serves to move this fossa in a progressively backward direction as the entire ramus grows posteriorly.

The ramus as a whole moves posteriorly by the combined growth processes outlined above, and as it does so brings about a corresponding elongation of the mandibular body by a remodeling conversion from former areas of the posterior-growing ramus into the lengthening body itself. Since the ramus occupies a position quite lateral to the axis of the body, a marked growth movement toward the mid-line is involved in the remodeling transition between anterior ramus and posterior body. This region of remodeling adjustment occurs in Area 10, and periosteal bone deposits on the lingual surface serve to carry the junction of the backward-growing ramus with the elongating body in a medial direction to a position corresponding with the line of the dental arch. The resorptive nature of the lateral side of the ramus (Area 4), in addition to providing generalized posterior and cephalic growth as noted above, also functions to move the anterior part of the ramus in a medial course as it becomes sequentially relocated and converted into the elongating but more medially positioned body. 
The periosteal surface along the inferior margin of the gonial angle is depository. This growth pattern brings about a general enlargement of the entire angular process by growth increase in a downward direction. The upper surface of the angular process faces away from this inferior direction of growth and is therefore resorptive in nature (Area 7).

Both the labial and lingual sides of the mandibular body (Areas 11 and 16) are largely depository. Periosteal bone deposits in these regions function to increase the size of the body in proportion to the overall size of the entire growing mandible.

A localized region of periosteal resorption with endosteal bone formation is present on the upper surface of the genial tuberosity (Area 12). This functions to move the tuberosity downward in combination with progressive bone deposition on its inferior surface. Also, periosteal resorption from the bone surface overlying the incisor teeth (Area 15) occurs in conjunction with a curving plane involved in the forward eruption of these teeth and forward and downward growth at the point of the mandible.

Numerous nutrient foramina perforate the cortical plate on the labial surface of the mandibular body (Area 14). The lining of these penetrating canals is resorptive.

\section{DISCUSSION}

A comparison of the general mode of mandibular growth in the rabbit and the human shows several similarities and differences. Parallels in growth and remodeling patterns are based on (1) the generally similar V-shaped configuration of the entire bone, (2) the presence of a growth center in the bulbous condylar head, and (3) a vertically placed, backward- and upward-growing ramus. The remodeling conversion from condyle to condylar neck follows the same sequence of inward, endosteal growth in both species. The presence of a posterior depository and an anterior resorptive surface on corresponding margins of the ramus is also similar further, the predominantly resorptive buccal side together with a depository lingual side of the ramus conforms to a common growth and remodeling plan. Generalized periosteal bone increases in most areas of the mandibular body are characteristic of both forms, and remodeling conversion from ramus to body follows a similar growth pattern.

Differences in growth are associated largely with regional differences in gross morphology. A prominent coronoid process is characteristic of the human mandible but is inconspicuous in the rabbit, and the complex remodeling sequence associated with this area in the human (ENLOw and HARRIs, 1964) is lacking in the rabbit. Also, a large, protruding lingual tuberosity is present on the lingual side of the posterior mandibular body in the human jaw (corresponding to Area 10 in the rabbit) but is only slightly represented in the rabbit mandible. As a result, this region in the human shows marked deposition of periosteal bone in the area of the tuberosity, a growth increase which grades proportionately farther back onto the lingual side of the human ramus as compared with the rabbit. The presence of this large tuberosity, further, is associated with an extensive region of resorption located just beneath it on the lingual side of the mandibular body. This resorptive area is concerned with the progressive undercutting of the projecting shelf of the lingual tuberosity as it grows in 
an upward and backward direction simultaneously. The absence of such a massive lingual tuberosity corrcsponds to the lack of this characteristic resorptive zone in the rabbit mandible.

Further growth differences are found in the forward mandibular angle at the point of junction between right and left halves. This area in the human becomes fused soon after birth but remains separated in the rabbit. The characteristic presence of a mental protuberance in man is associated with a complex sequence of cortical remodeling changes in the region of the chin. These particular growth changes related to the chin are not represented in the rabbit. The development of large, curved, tusk-like incisors in the rabbit mandible, however, involves restricted and localized areas of surface resorption (with endosteal bone deposition) in the overlying alveolar region of each incisor (Area 15). This is related to the depression of the area as the tooth erupts and moves in a curving forward direction and as the point of the mandible becomes extended in an inferior and anterior direction.

Acknowledgements--This work was supported, in part, by U.S.P.H.S. Grants DE 01903, AM 03865-07, and DE 02272.

Résumé-Les modes de croissance post-natale de la mandibule de lapin sont étudiées à la suite de rapports consacrés à la croissance mandibulaire et ses modifications chez Thomme et le singe Rhesus. Les méthodes utilisées sont identiques à celles des études antérieures. La répartition détaillée des surfaces d'apposition et de resorption des différentes régions mandibulaires est déterminée. A partir de ces données, des types globaux de croissance de cet os sont décrits et discutés. Les rapports des modificacations subies par les differentes régions mandibulaires montrent des similitudes et des différences entre la croissance post-natale chez le lapin et l'homme. Par suite de la similitude de forme dans les deux espèces, le type global de croissance est voisin et comporte une croissance condylienne, une réduction progressive du col du condyle et un recul de la branche montante. La surface linguale de la branche montante dans chaque espèce, est surtout formée par apposition et contraste avec la résorption notée sur les côtés vestibulaires latéraux opposés chez l'homme et le lapin. La croissance du corps mandibulaire est identique dans les 2 espèces. Plusieurs différences majeures sont cependant observées. Elles portent sur des détails d'anatomie macroscopique et comprennent en particulier des différences dans les apophyses coronoides, la tubérosité linguale et la région du menton. Les raisons de ces différences de développement sont discutées.

Zusammenfassung-Im Unterkiefer von Kaninchen wurden Untersuchungen über den postnatalen Wachstumsmechanismus als Fortsetzung vorangegangener Berichte über Wachstum und Formveränderungen des Unterkiefers von Menschen- und Rhesusaffen durchgeführt. Es wurde nach den gleichen Methoden wie in den vorhergehenden Untersuchungen vorgegangen. Die genaue Verteilung von angelagerten und resorbierten Oberflächen in sämtlichen Bereichen des Unterkiefers wurde festgelegt. Danach wurde dann der Wachstumsmechanismus im gesanten Knochen beschrieben und dargestellt. Es wurden die Beziehungen, die bei der Umbildung der verschiedenen Abschnitte des Unterkiefers eine Rolle spielen, fesigestellt und Åhnlichkeiten wie auch Unterschiede zwischen dem postnatalen Wachstumsmechanismus im Unterkiefer des Kaninchens und dem des Menschen diskutiert. Da eine allgemeine Åhnlichkeit zwischen der Form der Unterkiefer beider Spezies besteht, verläuft auch das allgemeine Wachstum einschließlich des kondylären Wachstumsprozesses der progressiven Verwandlung des Gelenkhalses und des posterioren Schubes des Ramus parallel. Die linguale Oberfläche des Ramus ist bei beiden Spezies vorherrschend appositionell geschichtet, im Gegensatz zu der resorptiven Eigenart der kontralateralen bukkalen 
Seite. Auch das Wachstum des Unterkieferkörpers ist bei beiden Spezies vergleichbar. Es bestehen jedoch vor allem anatomisch gesehen einige wesentliche Unterschiede im Umbau sowie Unterschiede im Muskelfortsatz, der lingualen Tuberositas und im mentalen Bereich. Die Entwicklungsbasis dieser Differenzen wurde erklärt und diskutiert.

\section{REFERENCES}

Enlow, D. H. 1963. Principles of Bone Remodeling. Thomas, Springfield, Ill.

ENLOW, D. H., and Harris, D. B. 1964. A study of the postnatal growth of the human mandible. Am.J. Orthod. 50, 25-50.

SCHEIMAN-TAGger, E., and Brodie, A. G. 1964. Lead acetate as a marker of growing calcified tissues. A modified method. Anat. Rec. 150, 435-440.

$Z_{A K}, D$. F. 1963. Lead acetate vital staining as a means of demonstrating bone growth patterns. $M$. S. Thesis, University of Illinois, Chicago, Illinois. 